DOI 10.37882/2500-3682.2020.08.13

\title{
ИДЕЯ ДУХОВНОГО БРАТСТВА В РАБОТАХ СИМВОЛИСТОВ
}

\section{THE IDEA OF SPIRITUAL BROTHERHOOD IN THE WORKS OF SYMBOLISTS}

M. Krasilnikova

Summary: The article aims to conduct a comparative analysis of the origins and main attitudes of symbolists to the idea of spiritual brotherhood, reflecting the peculiarities of the Russian soul. This idea was connected with those developed by D.S. Merezhkovsky, Vyach. Ivanov, Andrei Bely and other symbolists as carriers of a new religious consciousness, the concepts of spiritual revolution, world transformation, Theurgy, Cathedral symbolism and individualism, and cosmocentric reinterpretation of their role and purpose were used by Ivanov, Andrey Bely, and others.

Keywords: spiritual brotherhood, symbolism, national spirit, genuine Orthodox, all-humanity, spiritual revolution, national self-consciousness, conciliar individualism, life-creation, conversion.
И дея духовного братства в работах символистов имела ключевое значение, являясь подосновой и самого символизма как синтетического и многомерного течения в русской философии конца XIX-нач. XX вв. Дело в том, что тема духовного проникнута импульсами общинного, братского и всечеловеческого отношения людей друг к другу. И особенно это касалось самих символистов, сферы выстраиваемых ими межличностных взаимоотношений, способности слышать ближнего своего, откликаться на его потребность преодоления «бренных условий товарной культуры и ей обусловленной бренной рассудочной мысли» [4, с. 304].

В основе понятия братства (из праиндоевр. *bhrater-., а затем праслав. *bratrъ, от кот. в числе прочего произошли: ст.-слав. братръ, братъ (Использованы данные словаря М. Фасмера) лежит культивирование способности людей к сближению и объединению между собой, изначально составившее основу древнерусских «братин» в виде религиозной (православной) общины или монашеского ордена.

Символистами, являющимися яркими представителями русского духовного ренессанса, эта идея трактовалась сугубо как духовная в двух планах: необходимая для объединения братства самих символистов и отражающая суть народного духа, в его религиозно-соборном оформлении и трактовке. В первом случае эта идея представляла из себя некое скрепляющее начало, основу духовного единства носителей нового сознания и отношения к людям и миру вокруг, преображающее и реконструирующее межличностные взаимосвязи на
Красильникова Мария Владимировна

К.ф.н., старший преподаватель, Раменское приборостроительное конструкторское бюро marikras123@yandex.ru

Аннотация: В статье ставится цель проведения сравнительного анализа истоков и главных установок символистов на идею духовного братства, отражающую особенности русской души. Связана эта идея была с развиваемыми Д.С. Мережковским, Вяч. Ивановым, Андреем Белым и др. символистами как носителями нового религиозного сознания концепциями духовной революции, преображения мира, теургии, соборного символизма и индивидуализма, космоцентрического переосмысления их роли и назначения.

Ключевые слова: духовное братство, символизм, народный дух, подлинноправосланый, всечеловечность, духовная революция, национальное самосознание, соборный индивидуализм, жизнетворчество, преображение.

основе космоцентрического, по Н. Бердяеву, коммюнаторного, переосмысления их роли и назначения. Во втором - идея духовного братства представляла из себя основной мировоззренческий базис символистов, на котором они выстраивали свои концепции, связанные с попыткой изменения мира вокруг путем его одухотворения и усовершенствования.

Истоки идеи духовного братства в России были обусловлены мечтами о создании общины безусловно свободных людей: прежде всего славянофилов, В.С. Соловьёва, и других представителей сложившейся в XIX веке творческой интеллигенции, отстаивающих идею духовного обновления России. Последнее не могло быть осуществимым без глубокого осознания того, что представляет из себя национальный дух русского народа. Об этом пишет И. Солоневич в остро-критической форме по отношению к правящей в последние два столетия дворянской прослойке и выразителей ее чаяний «литераторов», обвиняя последних в безвольности и тех неопределенности и безвыходности XX столетия, в которых оказалась Россия. По его убеждению, правящие круги просто не способны постигнуть и отразить во всей глубине «идеалы русского народа», явившись «результатом разброда нашего национального сознания» [3, с 330]. Россия, по мнению И. Солоневича, «прежде всего - империя. Православная вера и внутренняя государственность, заложенные в фундаменте русского менталитета, самосознания, даже при его извращении - причины империализма России...Империя - это мир. Внутренний национальный мир» [8, с. 26] и «настоящая реальность таинственной русской души - её доминанта - заключа- 
ется в государственном инстинкте русского народа, или, что почти одно и то же, в его инстинкте общежития». [3, c. 332-333].

Так натурфилософично идею духовного братства и ее значения для возрождения русской национальной державности интерпретирует этот мыслитель. Но более важным представляется его неравнодушное и безапелляционное отношение к «правде русской души» - того нашего главного достояния, которое является маяком и основой истинно национального лица русского человека, способного на сочувствие и жалость не только к своим ближним, но и дальним, по сути, таковыми не идентифицируемыми. Это понимали те самые интеллигенты, которых обвиняет И. Солоневич в допущении революции. Это понимает и он сам. Но именно данный гуманистический аспект в наши дни, к несчастью, не всегда осознается современными представителями великой русской культуры. Отсюда происходят все беды уже XXI века и, в том числе, на международном уровне.

Именно поэтому целью нашей работы является рассмотрение установок символистов как представителей духовного ренессанса на идею духовного братства, отражающую главные особенности русской души. Проблемным является вопрос о возможности реализации этой идеи как на межличностном, так и на государственном уровнях.

В этой связи, основоположник славянофильского направления в философии А.С. Хомяков, в процессе рассмотрения вопроса об истоках духовного в русской культуре, национальное лицо русского человека трактует с точки зрения его принципиальной всечеловечности как не способного замыкаться в своей национальной фактуре. По этому поводу он пишет: «Чем менее человек закован в свою мелкую народность или чем народность его менее отрывается от жизни общего братства, тем легче историку воскрешать былое и узнавать неизвестное [9, с. 344]. Сила внешняя есть плод силы внутренней; пространство владений и вещественное могущество суть проявления могучего мысленного начала, и в многолюдстве племени (математическом превосходстве над другими) живёт свидетельство о духе братства, общения и любви. Да не забудется это чисто человеческое значение, чтобы не упала великая семья! Да не утратят счастливые потомки венца, заслуженного их многострадавшими предками!» [9, с. 450].

Другой представитель славянофильства К.А. Аксаков понятие братства связывает также с жизнью славянских общин, представляя этот феномен следующим образом: «При своих верованиях славяне русские образовали жизнь свою; они поняли значение общины, они ощущали чувство братства, чувство мира и кротости и многие общественные и личные добродетели. - Их игра: хоро- вод, круг - образ братской общины. Так жили они в чаянии христианства... Но отныне, узнав истинного Бога, он глубоко и навсегда наполнился истиной учения Спасителя» $[1$, с. 98]. Также здесь он пишет, что основа русской общины вполне истинна, так как личность признаётся в ней в своей свободе, а не в произволе; она не терпится в общине лишь в своей лжи, в эгоистическом бунте, а «артель есть росток, который пустила от себя община. До Петра система Руси истинна» [1, с. 104].

Отсюда славянофилами идея духовного братства трактуется как исконно национальное, свойственное славянским племенам и выведшее их на истинный путь общинно-национального воссоединения и становления единого христианского государства. При этом курс европеизации, взятый Петром I в XVIII веке ими осуждается как приостановивший этот единственно верный путь духовного объединения многонационального древне-русского государства.

С ними в этом не соглашается В.С. Соловьёв, считавший вклад Петра I в дело просвещения и обновления веры необходимым для общего блага и отражения подлинного духа православной веры. В своей работе «Византизм и Россия» (1896) он пишет, что заключаться последний мог только в нацеленности усилий церкви в лице ее патриарха на отстаивание основ добра и справедливости и борьбы против «действительных зол и бед народной жизни, а не «против невинных особенностей национального русского предания» или «во имя другого, тоже местного предания (греческого)», как это и было, например, при патриархе Никоне. [7, с. 221]. Принципиально важной для этого мыслителя являлась необходимость отражения «подлинно-православного духа», заключающегося не в одной только «автокефальности» церквей, а в отражении в деятельности собственно патриарха духа «действительно вселенского, универсального предания, которое по существу своему, даёт место всем особенным преданиям, не исключая, а обнимая их собою, как различные частные выражения той же всеединой и всеобщей жизни» [Там же].

Отсюда, по В.С. Соловьёву, дух подлинного братства может быть отражён «не в византийском «благочестии»», убравшем за скобки основные евангельские заповеди, среди которых главная - это «истинный Бог есть «Бог живых»», что на деле выражалось в, по сути, мертвой передаче духа веры в виде только «внешнего факта», «случайного и преходящего, тщательно консервируемого христианского предания, загражденного мертвящим буквализмом» вместо «существенного и вечного», (само по себе «замещение в византийских умах вселенского предания частным», по Соловьёву, обнаруживается уже в конце VII-го века, завершившись разделением церквей) [7, с. 222-223] и которое только и способно вывести отношения между людьми на подлинно христианский 
или братский, а значит, богочеловеческий уровень. Вне таких отношений между людьми идея духовного братства может получить форму «тёмного патриотизма» как основанного на видении существа благочестия в «незначительных местных особенностях русского церковного обычая» или якобы «истинного благочестия», отражающего «местные особенности», пусть и могущественного, русского государства вместо «веры Христовой, вечной и всемирной» [7, с. 227].

По мнению В.С. Соловьёва, подлинной политикой христианского государства должна быть христианская политика. Заключается последняя в представлении церковью перед своим государством «вечной правды, во имя которой оно должно управлять временною жизнью народов и вести её к высшей цели». В Константинополе одним из последних «в этом смысле» представителей церкви был «св. Иоанн Златоустый», у которого не было настоящих продолжателей и через несколько веков верховное управление византийской церковью стало принадлежать императорам, которым кроме царских воздавались и архиерейские почести. Это явилось причиной фактического превращения царской власти в Восточной империи из христианской в «Навуходоносорову», а, следовательно, «-и рокового крушения Византии» [7, с. 210].

Как особо отмечает В.С. Соловьёв, в Древней Руси были задатки «более правильных отношений между духовным и светским началами, между церковью и государством, но в силу исторических условий эти задатки не могли развиться, и «убиение св. митрополита Филиппа явилось на нашей почве самым ярким примером вавилонско-византийского деспотизма». [7, с. 210], как и возникновение «партикуляризма» в церкви [7, с. 226]. Первым, кто ясно осознал в новой России необходимость самостоятельного религиозного авторитета в истинном его смысле, - не как ограничения, а как восполнения самодержавной царской власти, а значит, добавим мы, понастоящему духовного общения с иерархами церкви и получения через них помощи свыше, был Петр І. [7, с. 211]. Выразилось это в его попытке безуспешного восстановления духовного авторитета церкви, которая натолкнулась на «византийский камень мертвого буквализма и византийскую змею лукавой лести» [7, с. 231]. Это и послужило причиной полного подчинения церкви государству и отмены патриаршества в России, замены его синодом, что «вполне отвечало истинному положению дела», так как самостоятельность духовной власти - это была только «фикция» [Там же]. При этом, как отмечает мыслитель, новая структура не была создана личным произволом, а вызвано это было «действительными условиями нашей исторической жизни», несмотря на то, что их никак нельзя было признать «нормальными с высшей точки зрения» [7, с. 232].

По этому поводу в работе «Жизненная драма Плато- на» В.С. Соловьев пишет об особом даре, сообщенном человеку Божеством, который выше другого тоже очень важного дара - «образованности», основанной на таких житейских обстоятельствах как «огонь» и «земледелие». Этот же «трижды величайший дар», согласно мифологии, был получен человечеством от Гермеса Трисмегиста и вложен в «телесный образ человеческого общежития» (выделено нами - М. К.) в виде «живой души и двигательницы жизни - философии, не для того, чтобы человек получил вечную истину и блаженство, а для того, чтобы трудовой путь человеческий к истине и блаженству огражден был с двух сторон - и от суеверного демонского трепета, и от тупой животной безотчётности» [7, с. 242]. В этом, согласно ведущей установке мыслителя, состоит и назначение истинной светлой христианской веры.

В рамках символизма как нового субъективно-художественного метода, суть которого впервые была изложена Д.С.Мережковским в лекции-манифесте символизма «О причинах упадка и о новых течениях современной русской культуры» (1992), идея духовного братства, во многом под влиянием трактовки этой идеи В.С. Соловьевым, рассматривалась мыслителем в связи с развиваемой им концепцией духовной революции и преображения мира, синтеза духа и плоти или интеллигенции и религиозного движения народа. Это было сопряжено с пересмотром назначения духовного не для отдельных представителей элитарного сознания, а для всего народа, жизнетворческого по своей направленности, содержащего в основе стремление к переоценке всех ценностей, в наши дни приобретающего сакральный смысл и возможность разрешения межрелигиозных и межнациональных конфликтов.

Так в статье «Красная шапочка» (1908) он пишет, что не от мощи государственной, а от мощи народной, без которой и в двенадцатом году Россия погибла бы, мы будем ждать спасения. Ссылаясь на главное свойство русской интеллигенции, определенное Достоевским как «всечеловечность», Д.С. Мережковский особо указывает, что последняя «неповинна в грехе национальной исключительности». При этом для русских людей любовь к родине не связана с тем, что «Струве называет государственною «соборною личностью», в отличие от идеи всемирного братства» [6, с. 435].

Другой представитель первой волны символизма в России К. Бальмонт идею духовного братства выразил в своих стихотворениях, отличавшихся особенной созерцательностью и философичностью. Его отношение к миру и людям вокруг, сложной, но неизбежной возможности разрешения всяческих недоговоренностей и конфликтных ситуаций раскрывается в цикле его стихотворений под общим названием «Выбор». Приведем одно из них: «Нет, мой брат, не принимаю /Гордый твой завет. 
Я иду к иному раю,/ Я люблю спокойный свет./ Ежедневный, ежечастный,/ Свет души на дне,/ Тем прекрасней, что, бесстрастный,/ Неизменен он во мне./ Брат мой, кто ты? Что ты знаешь /Обо всех других? / Ты неярких проклинаешь, / Я для них пою свой стих./ Ты сказал, что я сияю/ В капельке, в росе, -/ Это я благославляю, /Я желаю быть как все. /Все мы капли в вечном Море, / Нет различья в нас./ Все мы боль таим во взоре/ В наш последний смертный час./ Это - страшное проклятье:/ Презирать других./ Всех люблю я без изъятья,/ Я для всех пою свой стих».

Среди других продолжателей или, как он сам себя называл, «искателей» духовно-религиозного учения В.С. Соловьева, можно выделить имя главы второй волны символизма или «младосимволизма» в России Вячеслава Ивановича Иванова (1866-1949). Анализируя учение своего учителя, мыслитель в качестве основной его добродетели выделяет «добродетель справедливости», которая была его «живым иконопочитанием» [4, с. 340]. Отсюда, по Вяч. Иванову, учение великого русского философа следует трактовать как учение о «правом соподчинении отвлеченных начал, или об их универсальном оправдании» и о «восстановлении человека и природы в их божественности посредством свободного воссоединения всех движущих мировых сил в живой целокупности Тела Христова...Богочеловеческое или божественное тело (Церковь) составляет Невидимый союз душ, принадлежность к которой существенна, а не феноменальна. Благодатное действие на этот процесс оказывает Дух. Отсюда Церковь есть таинство вселенской любви и свободного единения во Христе», в связи с чем «история - это процесс становления богочеловечества, имеющего объединить сынов Божиих на земле и самое Землю» $[4$, с. 341].

В этих строчках Вяч. Иванова об отношении В.С. Соловьева к теме духовного единства человечества выразилась и его собственная позиция, которую он развивает в своей книге «Родное и вселенское». С его точки зрения, идею духовного братства следует трактовать через глубинное восприятие православия как «своей свободной родины и родину своей свободы» и веры в «Русь святую как в Русь вселенскую», где «русские мальчики» представляют из себя «тип людей нового русского сознания, напророчественный Достоевским и им порожденный», ищущих имманентно-трансцендентного синтеза в подлинном и вечном, как теургическом начале народного сознания [4, с. 165] Иванов пишет, что рост мифа из символа есть возврат к стихии народной. В нем выход из индивидуализма и предварение искусства всенародного как результата не личного, а коллективного, или соборного, сознания.

В позиции другого ведущего теоретика и неформального главы второй волны символизма в России - Андрея
Белого проявляется существенное отличие от позиции Вяч. Иванова, связанной с акцентировкой мифа, которому предшествует символ, как и на идею духовного братства. Определяя символ искусства как потенциал целой серии идей, чувств, волений, Андрей Белый утверждает его сотворяемость сознанием художника и производность из аллегории или мифа [3, с. 124]. Но самым главным отличием являлась акцентировка не коллективного, и даже не личного, а индивидуального сознания последним как способного составить основу чаемой ими всеми соборности или братства.

Сама идея, по словам поэта и писателя, родилась еще в студенческие годы, а в 1901-1902 годы он с Д.С. Мережковским и 3. Гиппиус активно обсуждает в письмах «тему о том, что есть религиозная община в новом сознании; моя религиозность не приемлет догмата, но символ Христа в лике и импульсе...» [3, с. 443].

Затем в 1903 году в одном из первых писем своему будущему духовному брату и главному соратнику по символистскому движению Александру Блоку он пишет об общении из «бессмертных далей» индивидуальностей, ищущих внутренней солидарности на основе соединения объективного и интимно-личного, пройдя разными путями промежуточную зону, лежащую между «внешним» и «внутренним» знанием, «соприкоснувшись с Одной Истиной» [2, с. 97]. В другом, уже ответном письме к А. Блоку, где тот называет друга «посвященным», которым может быть только он, так как «никто кроме тебя не услышит и знать не захочет» [2, с. 183], упрекает своего духовного брата за неопределенность выдвигаемых им целей и средств (реального пути) и упоминает о пути мистическом (как реальном), определить который помогает выбор мотивов долга и средств [2, с. 185]. Из данной переписки выявляется глубокая потребность обоих к творческому взаимодействию, пребыванию в «несказанном» [2, с. 191, с. 230], стремлению «ни к чему иному, кроме Правды» и - преображению личности, которое для А. Белого немыслимо без ясного осознания средств (реализации пути) и поставленных целей [2, с. 184].

Тема духовного братства теоретиком символизма непосредственно связывалась с развиваемым им учением о символах, в котором в центре оказывается заимствованное из работ В.С. Соловьева понятие теургии, определяемое как «ритмы преображения в нас», согласно которым он предполагает изменить мир к лучшему через «символизм, катастрофизм, взрыв: «Се творю всё новое...новое «я» и новое «мы»; мы - коллектив, община; она религиозна в смысле насыщенности её волевой энергией символизма» [3, с. 429].

Волимая мыслителем духовная церковь-коммуна или религиозная община предполагалась в значении человека и как духовно-революционное преодоление 
всех социально-общественных традиций в творимую новую культуру. Это и была поставленная им еще в студенческие годы цель построения соборного символизма, как аккумулирующая проблемы коммунизма и теургизма [3, с. 430-431] - «коммуна исканий, лаборатория опытов новой жизни в Символе, или «третьем», возникающем в нас как ведущий импульс. Строить её предполагалось в 1903-1904 годы друзьями-аргонавтами. В «Арго» А. Белый мыслил сидящим «Орфея»- «знак Христа: под маской культуры (для первых христиан - знак Рыбы)» [3, с. 437].

Сама его концепция заключалась в конкретной попытке построения отношений людей в обществе (для него в тот момент это были литераторы) на следующем принципе: «...никакое «Я» по прямой линии невыражаемо в личности, а в градации личностей, из которых каждая имеет свою «роль»...Неповторимость индивидуума («всегда коллектива») проявляется лишь в сочетании разных особенностей его внутреннего Я. Непонимание этого в нашей социальной жизни, неминуемо приводящее в оценке и себя и других в рамках поведения «личности», а не «индивидуальности», является причиной отсутствия у большинства всяких представлений о ритме жизни с другими, что...делает наши суждения о своих ближних превратными и является роковым законом гибели всех обществ, коммун, кружков, коллективов» [3, с. 430]. Отсюда происходили и его усилия разрешить проблему разобщенности людей в обществе, для чего он утверждает «индивидуум» в качестве «социального целого», выдвигая идею о наилучшем его проявлении в «церкви» или «коммуне-индивидууме», где «могли бы разрешиться противоречия многих личностей в самосознании каждого» [3, с. 421].

Позже А. Белый напишет, что «опыт, соединивший нас в попытке конкретизировать его, разбит; а меня упрекали в неверности;...я имел опыт другого рода: выстраданное знание о том, как перерождается социальный ритм в общественном коллективе, если его преждевременно опустить из духовной сферы в сферу душевности, где он - вихрь хаоса и астральная духота» [3, с. 438]. В данном случае речь шла о неправильно истолкованной платформе соборного индивидуализма, «названного Чулковым» и рядом других деятелей культуры того времени, включая Вяч. Иванова, А. Блока, Городецкого и Мейерхольда, «мистическим анархизмом» [3, с. 443].

Поэтому «с 1906 года с утопией о соборном индивидуализме было покончено» [Там же]. Саму же идею духовного братства позднее он пытается возродить в период своего увлечения антропософией как «старую мысль о коммуне эсотериков: мысль о братстве. Но, выходя к обществу, состоящему из тысячи членов, я постепенно разглядывал: неправомерное перенесение
Символов общины на учреждение «Общества» в фальшивом, ложноболезненном представлении о какой-то «эсотерической общественности», отличающей «Антр. О-во» от других, «светских» обществ... «общественность», переносимая в «братство», вносит в идею братства государственность; и эта государственность, принятая внутрь, безобразит внутреннюю линию отрыжкой традиций, гиератики, «орденства» и тому подобными пережитками; наоборот, идея братства, перенесенная в устав, и совет общества совершенно формальные юридические функции советников облекают в какие-то ритуально понимаемые обряды миссионерства: вместо свободного расключения линий получается безобразящая свободу сключенность, в результате которой ощущение «бочки», в которую тебя вклёпывают; в уставе «свобода», на кончике языка - философия свободы, а в действительности мироощущения епископский жезл, перед которым салютует в свободном порыве к... рабству». [3, с. 466]. В итоге в 1923 году А. Белый делает вывод о том, что «нужно отказаться от идеи общества в антропософии для возможности роста ассоциации духовно-свободных людей в их усилиях к грядущему «братству»» [3, с. 467].

Эта идея, развиваемая им и в поздние годы его жизни, также как и другими представителями символизма в России, основывалась на христианских и общественнореволюционных установках о единстве людей и народов, о всеобщей справедливости и свободе, и не могла быть реализована в предлагаемых условиях той исторической действительности, в которых находилась Россия первой половины XX века. Кризис символистского движения связан с пересмотром духовных ориентиров, отходом от изображения субъективных переживаний, попытками приобщиться к народной жизни. Претерпела существенное изменение и трактовка идеи братства, которое стало пониматься как всенародное. Деятели символизма этого времени пытались не просто теоретически рассуждать о позитивном изменении мира вокруг, но и выстраивать новые взаимоотношения в обществе единомышленников и людей, заинтересованных в одухотворении человеческой сущности и борьбой с «ледяной пустыней одиночества», как это делали Андрей Белый, Александр Блок, Дмитрий Мережковский, Вячеслав Иванов и многие другие символисты. И, несмотря на то, что в итоге символистское движение распалось, так как их концепции основывались на свободном, творческом проявлении личной или индивидуальной инициативы, что предполагало учёт разных точек зрения и некоторую сложность приведения их к единому целому, они делали одно общее дело, которое являлось их безусловной заслугой. И в первую очередь это касалось дела познания духовных глубин народной души, отстаивания национальных и общемировых гуманистических ценностей и поиска гармонии во взаимоотношениях людей. 


\section{ЛИТЕРАТУРА}

1. Аксаков К.С. Эстетика и литературная критика/Сост., вступ. ст., коммент. Кошелева В.А.. - М.: Искусство, 1995. - 526 с.

2. Александр Блок, Андрей Белый: Диалог поэтов о России и революции / Сост., вступ. Ст., коммент. М.Ф. Пьяных. - М.: Высш. Шк., 1990. - 687 с.

3. Белый А. Символизм как миропонимание. - М.: Республика, 1994. - 528 с.

4. Иванов Вячеслав Иванович. Родное и вселенское / Сост., вступ. Ст. и прим. В. М. Толмачева. - М. : Республика, $1994-428$ с.

5. К Красильникова М.В. Идеи синтеза искусства, бытия и сознания в творчестве Андрея Белого : монография /М.В. Красильникова. - М. : ИИУ МГОУ, 2015. - 208 с.

6. Мережковский Д.С. Избранное: Роман, стихотворения, эссе, исследования /Состав. А. Горло; Худож. С. Майоров. - Кишинев: Лит. Артистикэ, 1989. - 544 с.

7. Соловьев В.С. Избранные произведения / Сост., вступ. ст., коммент. Н.И. Цимбаева. - М.: Современник, 1991. - 525 с.

8. Солоневич И.Л. Народная монархия / И.Л. Солоневич; отв. ред. О. Платонов. - М.: Институт русской цивилизации, 2010. - 624 с.

9. Х Хомяков А.С. Церковь одна. Семирамида. / Сост., прим. В.М. Гуминский; Вст. Ст. Б.Н. Тарасов / Отв. Ред. С.А. Лыкошин, Союз писателей России. - М.: Информационно-издательская продюсерская компания «ИХТИОС», 2004. 324 с.

10. Фасмер М. Этимологический словарь русского языка: В 4-х т.: Пер. с нем. — 2-е изд., стереотип. — М.: Прогресс, 1986. - 562 с.

\section{( Красильникова Мария Владимировна (marikras123@yandex.ru).}

Журнал «Современная наука: актуальные проблемы теории и практики»

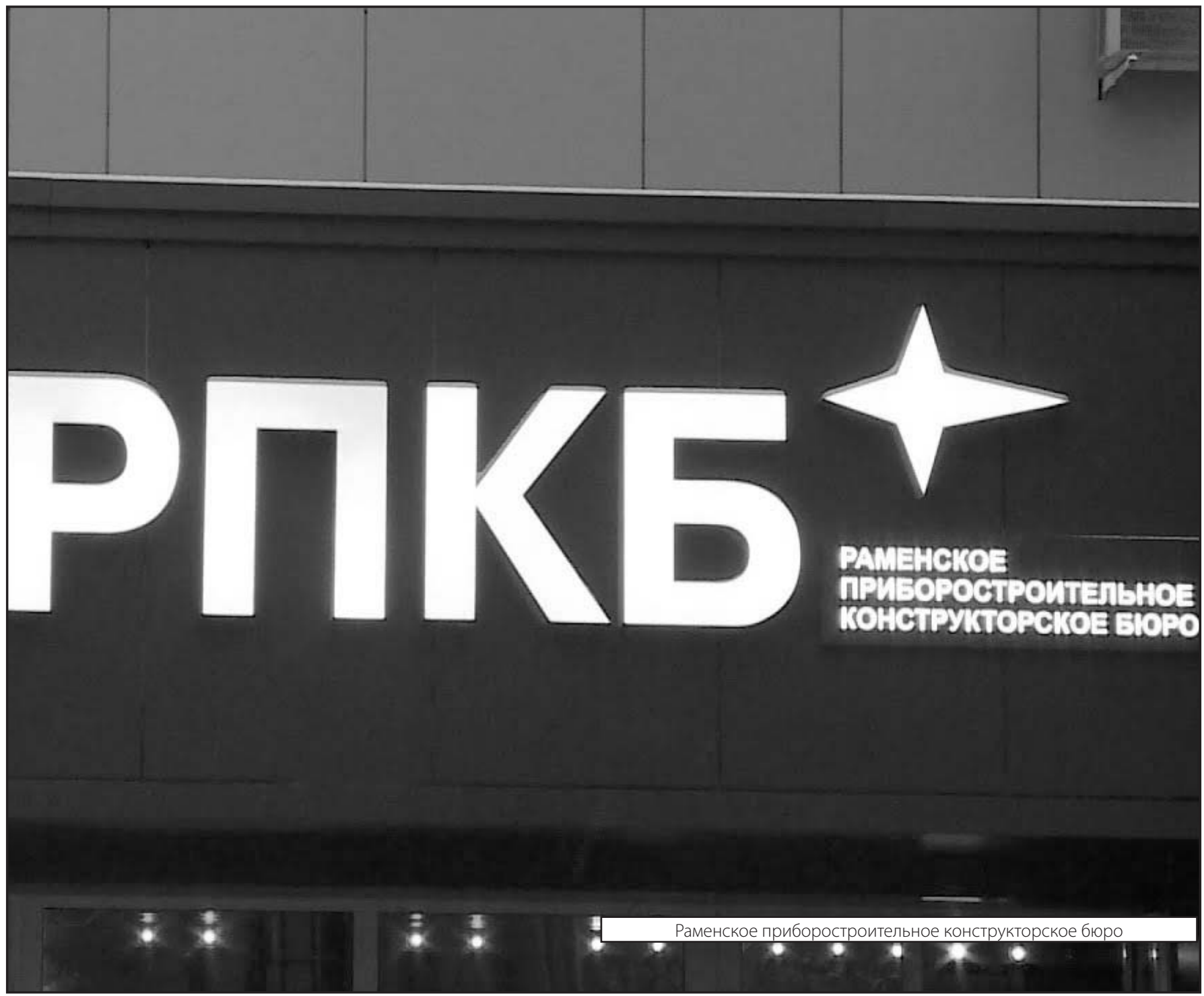

